ISSN: 1641-4713; e-ISSN: 2081-1160

DOI: https://doi.org/10.36551/2081-1160.2019.24.53-73

\title{
Body Image and the Ambivalence of Sugar as Heritage Among Cuban Dancers
}

\section{La imagen corporal y la ambivalencia del azúcar como patrimonio entre las bailarinas cubanas}

\author{
Ruxandra Ana \\ Institute of Ethnology and Cultural Anthropology \\ University of Warsaw, Poland \\ ID ORCID: https://orcid.org/0000-0002-6069-584X \\ E-mail: ruxandra.ana@gmail.com
}

Recepción: 20.02.2019

Aprobación: 31.08.2019

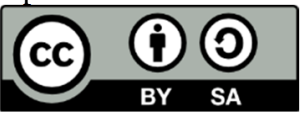

Abstract: The article looks at vernacular understandings of sugar as Cuban heritage in light of ongoing processes of westernization of Cuban foodways and body image. In doing so, I employ the notion of 'agnostic heritage' (Brumann, 2014) and the proposition of a 'third historicity.' The latter term includes the analysis of people's heritage experiences and beliefs, focusing on changes in local understandings of sugar as heritage, its ambivalence, and, at times, even stigmatization in relation to newly emerging canons and ideals governing body image. This article is based on ethnographic fieldwork conducted among female dancers in Havana's private schools over the course of approximately ten months from 2015 to 2018.

Keywords: dance, sugar, heritage, foodways, body image, Cuba

Resumen: El artículo da cuenta de la investigación sobre los entendimientos del azúcar como patrimonio cubano, en el contexto más amplio de los procesos de occidentalización de los hábitos alimentarios y de la imagen corporal de los cubanos. Se analizan las narrativas locales empleando la noción de 'patrimonio agnóstico' (Brumann, 2014) y la proposición de una 'tercera historicidad' que incluye el análisis de las experiencias y creencias de las personas, centrándose en los cambios en la comprensión local del azúcar como patrimonio, su ambivalencia, incluso la estigmatización en relación con los nuevos cánones e ideales que rigen la imagen corporal. El texto se basa en un trabajo de campo realizado en las escuelas de baile de La Habana entre el 2015 y el 2018 (10 meses), con la participación de bailarinas y profesoras de baile.

Palabras clave: baile, azúcar, patrimonio, hábitos alimentarios, imagen corporal, Cuba. 
When I arrived in Havana for seven months of fieldwork in September 2018, the first few days were mostly dedicated to small chores that needed to be done around the house, from minor repairs to renovation and redecoration. One day as I was preparing coffee for the small team of workers hired by Irma, the owner of the house I had rented, I pointed out to her that I had not yet managed to buy sugar (nor salt or any other basic products for that matter) and even though I knew too well that most Cubans drink their coffee with a little sugar, I asked if it would be a big mistake to offer the workers unsweetened coffee. 'The big mistake is that you've been in this house for four days now and you still don't have any sugar. Forget about the rest, we will slowly get you everything you need, but you can't stay without sugar', she told me, and dashed out before I even had a chance to reply. She came back a few minutes later with a plastic cup filled with sugar from our next-door neighbor.

A few days later, I was in one of the dance schools where I usually conduct my research, talking to Mireya, the owner, and waiting for our friend Marco to start his dance lesson. It was a particularly hot day and when Marco arrived, he appeared tired and confessed he was not handling the heat too well. Mireya gave him a disapproving look and said: 'I've been telling you this since you got here. How do you expect to live in a country with so much sun if you don't eat any sugar? You dance so much, you go to the gym every day, but you don't eat sugar. This is why you feel weak, this is why you don't have energy'. She was not the first dance teacher I had heard praising the virtues of sugar and the importance of regular sugar intake. Five years ago, my then dance teacher, Javier, would wait for me every morning before class with either small cakes or candies or even chocolate (if he happened to have other foreign students who would bring such small gifts), and before warm up he would say: Have your sugar, have your energy (Toma tu azúcar, toma tu energía). He explained on more than one occasion that the brain could not accumulate new information if not provided with enough energy, and the body would not respond properly. Mireya appeared to share this belief, although in a more nuanced fashion, which was revealed to me one day as we walked out the school and went for coffee, accompanied by three of the female dancers working for her at that time. As we sat down and placed our orders, she said she was craving ice cream and ordered some, inviting me to do the same, but not the girls: 'You see, we can eat sweets, because we already have boyfriends, but they need to stay in shape, or even lose some weight, if they want to find someone, so they can't have ice cream whenever they want'. 
Building on food consumption practices, ideals of beauty, and contradictory approaches to the female body, observations stemming from fieldwork conducted over the years among dancers and dance teachers in Havana's private schools, the article looks at vernacular understandings of sugar as Cuban heritage in light of ongoing processes of westernization of Cuban foodways and body image. I present local understandings of sugar as heritage, which include ambivalent and even stigmatized attitudes about the sugar in relation to newly emerging canons and ideals governing body image, by employing the notion of 'agnostic heritage' (Brumann, 2014) and the proposition of a 'third historicity' which includes the analysis of people's heritage experiences and beliefs.

The material for this article was collected during approximately ten months of fieldwork in Havana during the period 2015-2018. My current research project (ongoing since 2015) looks at the touristic, political, and economic uses of intangible cultural heritage, by focusing on dance practices and their dissemination among international tourists through classes and workshops in Havana's private dance schools. Long term participant observation and interviews conducted with dance teachers, dancers, and dance school owners brought up several issues related to their everyday lives, which were beyond the initial scope of my research project. Training together, going out together, cooking and eating together with many of my research participants have revealed important aspects related to perceptions of food, diets, body image, and ways of defining the dancing body; these observations constitute the basis for this analysis. I gathered material on the history of sugar and sugar as Cuban heritage during four trips to Trinidad and the surrounding Valle de los Ingenios over the past five years.

The first section of this article looks at the relation between sugar production and the development of Cuba as a nation in the broader economic and cultural context of the region, while looking into its particularities as a heritage site in the Caribbean dedicated to the sugar industry. Along with tobacco, sugar has functioned as a vehicle for transculturation (Ortiz, 1995), being one of the main commodities that shaped society and, eventually, a nation. Currently, sugar-related heritage tourism remains the main industry in parts of the country (Trinidad and Valle de Los Ingenios), with Cuban heritage tourism being more generally a means of nation-building and instilling civic pride (Sanchez, Adams, 2008). The second section analyzes sugar as staple food in Cuban society in the broader context of Cuban foodways and the transitions of late socialism. In a country 
characterized by a centralized distribution system and state-defined nutritional needs, where food scarcity and improvisation have become commonplace after the Cuban revolution of 1959, food consumption has been defined mainly in terms of levels of nutrition and less in terms of satisfying particular taste preferences (Wilson, 2009). However, recent developments in the private sector, the rise in international tourism, and the increased availability of certain products, although at very high prices, have reshaped practices related to food consumption among certain groups. Such is the case of the dancers among whom I conducted research: staple foods rich in refined carbohydrates (bread, sandwiches, pizzaall of them easily accessible in the streets of Havana), and sugar in particular, turn out to be the source of extreme ambivalence.

\section{FROM PILLAR OF THE ECONOMY TO WORLD HERITAGE SITE}

Sugar cultivation and exports have played a dominant role in the Cuban economy for centuries, transforming sugar into a monocrop that, on the one hand, served the accumulation of foreign capital but, on the other hand, marked Cuba's vulnerability on the international stage and its dependence on Spain until the late nineteenth century, the United States until 1959, and the Soviet Union until 1991.

Sugar production in Cuba dates back to the sixteenth century, yet it was not until the Haitian Revolution of 1791-1804 that it started operating on large scale, a result of the rapid decrease in sugar production in neighboring Saint-Domingue. The rebellion caused thousands of casualties and led to the destruction of almost one thousand plantations (Galván, 2004), a situation that the Spanish crown was quick to seize upon by removing taxes for sugar exported from Cuba. As sugar production increased in order to satisfy the demands of the European market, Cuba became the richest Spanish colony by the mid-nineteenth century. An estimated 550,000 slaves (Curtin, 1969) arrived to Cuba between 1811-1870, despite international agreements between Cuba and Spain to end slavery. During the first decades of the nineteenth century, Trinidad had established itself as the first great city of the Cuban sugar industry, and the profitability of sugar production soon became visible not only in the elegant plazas of the city, its cobblestone streets, and beautiful houses, but also in the grand mansions of slave owners and the towers overlooking the sugar production process. The tallest one, and one of Cuba's biggest tourist attractions, is the Iznaga Tower (in Valle de los Ingenios, outside Trinidad). The 45-meter tower was constructed in 1816, displaying a massive bell 
that marked the beginning and the end of the workday, but that also doubled as alarm in case any of the slaves ran off.

The rural landscape was also severely modified by the expansion of the sugar industry, leading to the decimation of forests and sometimes even the replacement of coffee or tobacco plantations. As the Cuban economy grew based on sugar exports, working conditions for the slaves on the plantations remained extremely difficult. Production increased from 322,000 tons of sugar in 1853 to 392,000 tons in 1855 (Zanetti, Garcia, 1998). The mid-nineteenth century also saw the construction of the Cuban railroad and technological advances that reshaped the sugar industry, facilitating the connection with external markets and leading to the division of the sugar industry into sugar production (in the fields, work performed by slaves) and sugar processing in ingenios (sugar mills). By the end of the nineteenth century, after three wars for liberation from Spain, the Cuban sugar industry was severely affected by the war and in many respects the U.S. had replaced Spain as a colonial power. In March 1901, with the passing of the Platt Amendment, the U.S. Congress placed a series of limitations on Cuban rights while expanding American powers over the Cuban government. With U.S. intervention having crushed José Martí's ideal of an independent Cuba that transcended racial divisions, visions of equality and social justice were replaced by a colonial hierarchy under American influence, and the economy was to be rebuilt by reviving the sugar industry rather than ensuring a diverse and somewhat more self-sufficient system. As pointed out by Pérez:

If Cubans recognized that the road to independence was paved over the wreckage of colonial economy, Americans, for their part, recognized that hegemonial relations with Cuba depended on reconstructing the sugar system (...) Indeed, no strategy was so central to the goals of annexationists as the reconstruction of the sugar export economy (1983: 348).

As investments were encouraged by this neo-colonial system, American capital quickly gained control not only of the sugar, mining, and tobacco industries, but also of real estate and construction. Furthermore, the U.S. sugar quota, specifying the amount of sugar that could be sold by Cuba at a subsidized price, became essential for economic planning.

A 'wrong' decision that might upset one U.S. senator cold lead to a filibuster against Cuba's quota. And so, for example, although Cuba had the potential to produce tomatoes and even tomato catsup commercially, both were imported from the U.S. because of U.S. tomato growers (Brenner et al., 2015: 5).

The overthrow of the Batista dictatorship in 1959 was the result of a revolutionary movement aimed at modernizing the country, raising the living standards and getting rid of corruption. A series of radical changes were implemented, 
including the Agrarian Reform Law and the Urban Reform Law, as the country turned to a socialist planned economy. As a result of these reforms, much of Cuba's rural property was nationalized, and Cubans with more than two properties were obliged to turn over excess holdings to the government, setting in motion massive redistribution from rich to poor. When President Eisenhower put an end to U.S. imports of Cuban sugar in 1960, the Soviet Union stepped in and purchased the sugar destined for export to the U.S., thus initiating a trading tradition that would make Cuba dependent on its production of sugar. However, tensions between the two countries escalated in the 1960s. The already fragile economy was affected by Hurricane Flora, which caused severe damage and loss, sugar and food production declined, and in 1968 the Soviet Union announced its decision to provide Cuba with less oil. All of these factors contributed to the creation of a government strategy aimed at achieving the goal of ten million-ton sugar harvest in 1970, ultimately making Cuba self-reliant by providing it with enough hard currency. However this historic harvest had other meanings attached to it, too, as pointed out by Tomé: 'the sugar campaign of 1970 marked the culmination of the social experiment to create the New Man. Launching this historic harvest, Fidel Castro stressed that the desired yield could be achieved only through utmost workplace discipline, patriotism and «everyday heroism»' (2017: 13). The result of this campaign was that the entire economy was subordinated to meeting this goal, and economic planning became closely tied to the Soviet Union. By 1980, earnings from sugar exports to the Soviet Union and Eastern Europe had reached a higher level than exports to the U.S. in the 1950s, and by 1989 sugar accounted for more than 70 percent of Cuba's export revenues (Pollitt, 2010). But with the collapse of the Soviet Union, and the disappearance of its main market for sugar exports, Cuba was faced with what Fidel Castro called the 'Special Period': a time of rapid fall in gross domestic product, dramatically lowered living standards, food shortages and overall hardships exacerbated by the tightening of the U.S. embargo. The acute lack of foreign currency led to the reorientation of the economy towards tourism, a sector that was initially seen as a 'necessary evil' but came to be what sugar used to be before the fall of the Soviet Union: a single commodity in the service of the accumulation of foreign capital.

Tourism, and specifically heritage tourism, became a means to rebuild the nation. In line with revolutionary ideology, it highlighted historical and artistic colonial culture, displaying a romanticized image with wide market appeal (see Lasansky, 2004). The tourism industry and local institutions faced several challenges in clearly pointing out the specificity of the destination, especially as in 
terms of Caribbean tourism, the most commonly recognized symbols related to climate and landscape, architecture, music and festivals. Shaped by slavery, colonialism and plantation culture, Caribbean heritage displays qualities that once again underlines its unique character: a mix of races, languages, architecture and fortifications as a result of colonial past, a variety of religions, and topography. With indigenous heritage almost totally destroyed, most of the countries in the region had to focus on colonial and Creole heritage (Honychurch, 2003).

Heritage tourism became one of the main sources of revenue across the island, including Trinidad and the adjacent Valle de los Ingenios (Sugar Mill Valley), declared a UNESCO World Heritage site in 1988 (Scarpaci, 2005), under the following criteria:

(iv) Shaped by the region's 18th- and 19th-century sugar industry, the exemplary city of Trinidad owes to sugar its continued existence and its historical raison d'être, which is clearly legible in the existing built environment of the city and the nearby Valley de los Ingenios and (v) The Valley de los Ingenios is a remarkable testimony to the development of the sugar industry and a living museum featuring 75 former sugar mills, plantation houses, barracks and other facilities related to this vulnerable industry.

The landscape outside the city had been strongly modified by sugar plantations, mills, and the railroad built to carry sugarcane to the factories. The steam engine, on tracks laid to carry sugarcane from the farms or the sugar factory, symbolizes the transition of the sugar industry to industrialization (Pollitt, 2004) and is now one of the biggest attractions in the valley. The round-trip ride from Trinidad takes around five hours and is highlighted by most tourist guides as one of the 'must do' activities in Trinidad, as it includes a visit to the observation tower Manaca Iznaga, used by slave owners to watch over the slaves. The nearby colonial restaurant, located in the house of the former estate owner, offers 'traditional Cuban food' and occasionally live performances. Guarapo (juice extracted from sugar cane) stands located across the street from the train station and souvenir stands along the path leading to the tower complete the experience of this first stop. Yet with the lack of a local guide, many tourists feel lost, as there is virtually no information offered on the history of the plantation or on the more general history of sugar production in Cuba (with the exception of the maps printed on big boards on the way to the tower). The second stop is at FNTA, which opened in 1915, was owned by North Americans until 1959, and operated as a sugar mill until 2002. The site is currently undergoing restoration with the intention of being transformed into a museum, but for the time being displays massive equipment imported from the U.S. and countries of the former Soviet Bloc. While the site is neither fully reconstructed nor officially open, visitors are 
given the opportunity to walk around the premises and observe the facilities. On my last visit to Trinidad in December 2018, local guides were available, offering brief information on the history of sugar production in the area.

While locals and officials alike praise the city and tourists label it as an unmissable spot on the island's map, Trinidad rests and capitalizes on its World Heritage status. But this precious resource turns out to be quite precarious. As a tourist attraction, sugar heritage remains rather underdeveloped, its full potential not yet exploited, an issue pointed out by Inniss and Jolliffe in their discussion of former sugar industries in the Caribbean:

...with their contested labor practices being represented by the history of enslavement and indentureship, interpretation of former plantations and industrial processing of sugar may provide a means for discussing the contested past for the local populations, while at the same time developing industrial heritage products with the potential to contribute to the diversification of local tourism industries (2012: 94).

However, regardless of tourism policies and promotion strategies for World Heritage sites, sugar remains a powerful presence in everyday practices, a staple food believed to be a source of energy and nourishment, and in recent years mainly through contact with dancing tourists, and their imaginaries and expectations around Cuban dancing bodies - an undesirable food, impeding one from attaining a perfect figure. In analyzing these aspects in the following section, I engage with the notion of 'heritage agnosticism', by looking into 'ordinary people's engagement with the things and practices labelled heritage, disclosing the often bewildering multiplicity of voices and practices surrounding it' (Brumann, 2014: 180). I discuss sugar from a grassroots perspective, bringing forward the meanings attached to it not just in terms of nation building, but in terms of everyday practices.

\section{ENERGY BOOSTS, FLEXIBLE WORK REGIMES, AND BODY IMAGE}

The 1959 Revolution of brought about a series of changes in all major aspects of Cuban life, including the food system: even though the purchasing power of the population was higher, low productivity, and therefore access to food, was a direct result of the agrarian reform. As food became scarce, the libreta de abastecimiento (rations booklet) was introduced in 1962, rationing the food with the purpose of guaranteeing the caloric and protein intake. Although at the time Prime Minister Castro predicted the libreta system would end by the mid-60s (Alfonso, 2012), it continues to exist today, with the distribution system still centralized and guided by nutritional needs that are defined by the state. One of the direct 
implications of this distribution system is the increased attention given to calories and levels of nutrition to the detriment of taste and food preference. Issues related to food scarcity and food security became a double-edged sword, showing either support for the Revolution or criticism against it (Alvarez, 2004). On the one hand, the booklet was seen as a means of providing the population with regular supplies, but on the other hand the system was deemed incapable of maintaining a constant level of food production. Subsidized products can be bought at government-run distribution centers called bodegas and distribution quotas take into account consumers' age and health status, with detailed records kept by the Consumers Register Control Office (Carter, 2013).

Food scarcity and the need for improvisation reached a new peak after the collapse of the Soviet Union and the beginning of Cuba's Special Period. In just three years, GDP collapsed by more than 30\% (Krohn, 1999) and the consequences of this critical moment in Cuban history were exacerbated by the ongoing U.S. embargo, tightened by the Torricelli Law in 1992 and the Helms-Burton Act in 1996, bringing the Cuban economy close to collapse. Cubans faced extreme poverty, and inequalities and social stratification were further deepened by a 1993 reform that allowed Cubans to own American dollars-introducing, de facto, two parallel denominations-in order to facilitate commercial exchange. Later on, dollars were replaced with the second official currency, the convertible peso (CUC). The Special Period brought about the 'eating for survival model' (Alfonso, 2012): one would eat the things that were available (if anything was indeed available), not the things one might prefer. An increased variety of available food products became noticeable as the country slowly started encouraging the development of the private sector and made international tourism a priority. As tourism began to quickly develop in the late 1990s, the existing infrastructure turned out to be insufficient. The government legalized alternative forms of accommodation for foreign visitors in local family homes (casas particulares), which created opportunities for individual business to develop. The other successful business in Cuba's still heavily state-controlled economy were private restaurants known as paladares. This attempt to respond to tourist needs brought about several changes in Cuban food scene, including serving fresh fruit and seafood as well as diversifying breakfast and brunch offerings, typically at prices unaffordable for locals. The tourist sector has remained isolated from the rest of the economy since its very beginning (Espino, 1993), resulting in economic inequalities that in turn led to social stratification. 
When Fidel Castro officially stepped down in 2008 (Raul Castro had already been appointed acting President of Cuba in 2006), the country entered a new era of economic reforms, which redefined the relations between state, society and individual without abandoning the socialist model. As Raul Castro authorized several categories of self-employment (cuentapropismo), the private sector became a symbol of economic and political transformations in the country. Private entrepreneurs are considered key players in the transition from socialism to a free market economy (Phillips, 2006). Further changes took place when, in 2014, Cuba and the U.S. restored diplomatic relation that had been suspended since 1961: the embassies in Havana and Washington were reopened, sanctions on financial transactions with the island became less severe, several travel bans were lifted, and Cuba was removed from the list of state sponsors of terrorism. Not only did the country re-enter the spotlight and headlines of international media, but tourism boomed, international arrivals reaching almost four million visitors in 2016. However, the reopening was short lived, as President Donald Trump implemented a more restrictive policy towards Cuba. The past two years have seen two rather difficult high tourist seasons. My research participants referred to 2017 the lowest high [la alta más baja] in many years, with a significant decrease in international arrivals, explained by many Cuban entrepreneurs as a direct result of 'Trump propaganda' coupled with natural catastrophes, including hurricane Irma, an extremely powerful and catastrophic hurricane that hit the island in 2017. The country's economy and its food system remained vulnerable and unstable (partly because of the damages caused by hurricanes, droughts, and floods), while food choices remained dependent on policies of distribution. As pointed out in an analysis of Cuban foodways and tourism, there is a strong contradiction between 'the way food is treated in a socialist economy - as a basic entitlement - and food as a desirable commodity in the market economy' (Ana, Lubiński, 2014: 125).

The 'eating for survival model' that characterized the Special Period was adapted and transformed into 'eating what is available' or 'eating what could be found' (lo que hay, lo que se pudo encontrar). Such meals, improvised from the available products, often fail to meet the expectations of what is considered a 'decent meal', or what is framed as 'alimentary dignity' (Garth, 2019). Even in times of relatively increased availability of certain food products, it is very common to hear Cubans say they are going 'to search' for food, instead of going 'to buy' food (voy a buscar vs. voy a comprar). While the search may sometimes last hours and entail complicated networks of food distribution, from fruit and vegetable markets, street vendors, and dollar shops to the black market, more often 
than not it results in finding enough products to be able to cook for the day. However, it is quite common to hear Cubans say, 'there is no food' / 'there is nothing' ( no hay comida / no hay nada), even though they do manage to buy products and prepare the meals. The quest for food and the rejection of the meals prepared as a result are described by Garth (2017) as resistance strategies employed by $\mathrm{Cu}-$ bans in order to deal with the ongoing changes in the food system. While the first strategy (part of la lucha, the fight for basic, daily commodities or services usually difficult or impossible to attain by official channels) reveals the struggle necessary to obtain food products when the monthly ration is used up, the second one is a type of discursive resistance (Garth, 2013) understood as a socio-political commentary that emphasizes the degree to which available food is considered inappropriate. The Special Period became a reference point in discussing the food crisis, as expressed by Isabel, one of my research participants, who runs a casa particular and a dance salon:

It's almost as if we were facing another periodo especial, this is how difficult it became to find food. You go to the shop, empty. Markets empty, and if you do find something, it is so expensive you can't afford it.

The conversation continued with a suggestion I had heard before in Havana: 'At the end of the day, you drink some hot water with sugar and it cuts your hunger (y te quita el hambre)'. Isabel's comment displays a belief in the virtues of sugar that is not uncommon among Cubans of all ages and social backgrounds. This may be linked to practices common in the nineteenth century, when sweets were produced on every island of the Caribbean and sold in shops, taverns, or door-to-door, sometimes even provided as 'gifts' to workers, as it boosted energy (Goucher, 2015). Furthermore, it is believed to be the ultimate source of nourishment when all else becomes unavailable. Sugar's 'ritualization' (Mintz, 1986: 122 ) is related to the swift sensation of satisfaction it provided, but also to the meanings attached to it by the ones who consumed it, meanings specific to their social and cultural position.

Isabel was not the only one to express the idea that sugar was filling, nourishing, and tasty (it is not uncommon for many Cubans to describe everything that is not sweet as being amargo [bitter]). Luis, a former member of a dance company and dance instructor in a private dance school at the time of our interview in 2016 shared the following story:

After graduation, I needed to make a living, to survive somehow. I came to Havana but I didn't have where to live, I needed money to rent a room, to eat, to buy clothes. I had to make it, somehow, because there was no way I could go back to Santiago, where there is another economy, I wanted to help my mom. So, I started teaching tourists. I taught myself 
English (...) I was studying without eating for three or four days, I'd only eat sugar, and it was very tough, but this is how I got to where I am now, without asking anyone for anything. Not money, not food, not clothes, nothing that could destroy my image of professional dancer. I had to fight for everything I have.

While Luis and Isabel share the belief in the energy-boosting properties of sugar, Luis relates food scarcity issues to questions of professionalism and, in a way, pride. While acknowledging that the sacrifices he made are not a secret and had shaped his career, he points out that there are certain boundaries that, if ignored, could seriously damage the image of the professional dancer / dance instructor. What is noteworthy here is that these boundaries are not related directly to the teaching aspect of the dancer's career, nor to the formal interaction between instructor and client. There are several reasons why this happens. First of all, contacts between dance teachers and tourists are not always restricted to the dance lesson, as for many tourists dance teachers are the first (and sometimes only, perhaps with the exception of casa particular owners) interaction with locals, and these interactions can lead to a certain type of attachment and friendly relationships, which lead to spending time together outside the school venue. Second of all, many schools have started including as part of their offerings the services of a taxi dancer - usually a dancer or dance teacher employed by the school who, for an additional fee, can accompany clients on a night out in order to practice their skills in one of the city's salsa venues. Many dance school owners are very strict about the rules that govern teacher / client interaction, and two of the most widespread and commonly discussed rules deal with food and romantic involvements. While it may be accepted that dancing may lead to emotional entanglements that are out of the employer's control, many of the dance school owners I talked to stress the importance of not asking tourists for anything - especially food, money for food, or money for taxis to return home after a lesson or a night out. Last year one dance school owner told me a story of one of her employees who during a night out as taxi dancer had asked her client to buy her food, and as a result the next day she got suspended for two weeks. As she explained, 'it is important for them to understand this, of course tourists come here knowing the difficult situation of the country, they see poverty, they see all the problems, but you are a professional, you take money for your work, you can't behave like a beggar, because this ultimately affects all of us'.

A similar point of view was expressed one night over dinner by two dancers working at Mireya's school. They explained that because of all the difficulties and necessities in the country, and especially as tourists tend to grow attached to their dance teachers, lunch or dinner invitations are not uncommon, and they are 
not a problem as long as they are not requested. In their opinion, this would be unprofessional behavior that could attract sanctions from the school owner. At the same time, going out with one's clients is not usually seen as a bad thing. As we placed our orders, they mentioned they were in a hurry (as they were both taxi dancing that night), and asked for tres leches with ice cream to be brought first, just in case they wouldn't have enough time to wait for the food, as explained by Yunaysi: 'Dessert is my favorite food anyway, and sugar is good because I have to dance a lot tonight, so I need energy, and besides if I don't have time to eat, sugar fills me up'. While her comment relates strictly to the nourishing and energizing properties of sugar, Yunaysi is not alone in her sentiment. Many of the female dancers I worked with praised sugar for the same reasons, yet the common perception is that there is a downside to its consumption, directly related to the way sugar intake affects their diet and body image. Diets are common conversation topics, as is the need to lose weight, in order to adhere to a certain set of beauty standards, as discussed in the following section.

\section{LUCHADORAS, BEAUTY STANDARDS, AND FOOD INSTABILITY}

A closer look into the complicated systems that are required to navigate food scarcity and food instability, but also into the patterns of food consumption and local ideals of beauty, reveals the gendered division of labor in Cuban households and the beauty standards to which women are subjected.

Before 1959, middle class women employed domestic workers (generally non-white, see Folch, 2008). However, after the revolution Cuban women were encouraged to become an active part of workforce; the image of the ideal revolutionary woman was juxtaposed with that of the good mother, also reflected in the logo of the Federation of Cuban Women (Federación de Mujeres Cubanas), which depicted a woman in military clothes holding a baby and a gun. 'All women as mothers or potential mothers not only are responsible for the care of their families but also, by extension, are endowed as caretakers of the revolution and, thus, the nation' (Davidson, Krull, 2011: 62). The FMC, founded in 1960, was initially established to mobilize women into workforce, but evolved into an organization aimed at promoting gender equality (Smith, Padula, 1996). As pointed out by Kirk (2011), 'Cuban feminism does not fit into the typical frameworks of Marxist, Socialist, Liberal, or even Third World feminism. Rather, Cuba has encouraged the development of a unique form of feminism that is based on universal values and Cuban revolutionary ideology' (148). However, traditional 
gender roles remained dominant, and continued to place strong emphasis on motherhood and heterosexuality, being intimately related to a kind of machismo deeply embedded in Cuban culture. Rooted in almost four centuries of Spanish colonial rule, it portrays the ideal man as hyper-masculine, virile, strong, sexually dominant and unfaithful (Kirk, 2011), while at the same time mystifying women's sexuality. Complementary to Cuban machismo, hembrismo stands out as a new ideal of Cuban womanhood, emphasizing sensuality and sexual prowess (Hryciuk, 2009) but also strength and resilience, drawing on post-revolutionary emancipation (Daigle, 2015). Despite the achievements and expectations in terms of social equality, the economic crises that characterized Cuba in the past years have been deeply gendered. The Período Especial made things even more difficult, as house chores, regarded as almost exclusively women's responsibility, became more time consuming and challenging because of limited resources. This reinforced the idea that women are domestic 'experts' solving problems, doing the work, saving money, knowing what products to buy so that they would not be overcharged. The image of the hembra, therefore, is juxtaposed with that of the luchadora - a person of great resourcefulness and strength, who relies only on herself within la lucha (a widespread concept in Cuba, referring to the daily struggle of making ends meet), therefore emphasizing a different type of womanhood in contrast to the passive, reserved femininity ascribed to marianismo.

In the case of the dancers with whom I worked, the pressure of running a house and, often, looking after children was doubled by the pressure coming from their work, even more so if they were dance teachers and dance school owners, as is the case of Mireya, who one day told me the following:

I've been thinking a lot about cutting my stomach lately. You see, it would be good for the business, because you know how people think dancers should look like, and I am very far from that. But let's say I do it, and then one month I cannot come to school, I cannot work, who is going to replace me? Nobody. Who is going to take care of my children? Nobody. I have a lot of work to do at home, a lot of work at school, sure, losing weight would be great, but who has the time for this?

Mireya's comment shows a desire to change her looks in order to correspond more to an imagined ideal body of a dancer, strongly informed by Western ideals of beauty and fitness, and the limitations imposed on that desire. It is important to note that dancers in private dance schools aimed at teaching foreign tourists do not come from institutions that train professional dancers, therefore subjecting them to disciplining regimes. Whereas pre-revolutionary Cuban corporeality was strongly associated with rhythm, sensuality, and excess, such associations diminished by the 1980s, as popular dance in Cuba declined, through the closure of 
bars, clubs and cabarets. The symmetry and discipline reflected in ballet bodies, which ultimately became a revolutionary pedagogic device, 'functions as a metaphor for the state's desire to have docile female bodies who provide aesthetic and libidinal pleasures but must be trained and regimented for the fulfillment of state goals' (Blanco-Borelli, 2016: 175).

Cuba's reopening to international tourism brought back into the spotlight the oversexualization and commodification of the female body; the sensual mulataa mixed race, European-African woman - became a key symbol in tourist advertising, which, not surprisingly, was met with harsh criticism from the Federation of Cuban Women: 'Part of the present tourist and commercial adverts employ women as simple object of advertisement with aims and interests similar to those of lowest-quality advertising in capitalist countries'.

While the image of the ballerina is a strong presence in the Cuban imaginary when it comes to grace and elegance, ideals of beauty remain informed by the image of the mulata, as a symbol still strongly put forward by the tourism industry. However most recently, through the increased popularity of salsa festivals worldwide, the references become Cuban dancers who had managed to build a career abroad and became famous on the international salsa scene. Images of fit, thin bodies are communicated through social media (to which Cubans have had increased access in the past two years), but far more widespread are such images in reggaeton videos. Their availability in bars, restaurants, beauty parlors, and even private taxis make such images highly accessible.

But Mireya's comment on weight loss and body image points out another important aspect: private businesses lead to a restructuring of labor routines and an overall change of temporal structures, bringing changes in work discipline and erasing the line between work and free time (Chelcea, 2014). Functioning outside the state regulated system, many of the self-employed dancers and dance school owners enjoy a kind of newfound independence and a sense of freedom that the state sector lacks. The kind of flexibility required by the private sector, the need to be fully available at any time, depending on the dancing tourists' schedules and lesson planning is often juxtaposed with the instability and unpredictability of food distribution systems.

Although as seen in the opening vignette, Mireya, and many of her female dance colleauges, is a firm believer in the body's need for sugar, especially in warm climates. When discussions turn towards dieting and weight loss (and usually they do at least once a day, as there is always someone on a diet, or planning to start one), sugar is singled out as the biggest evil. I asked my research partici- 
pants what were the reasons that did not allow them to cut down on their sugar intake or eliminate sugar altogether from their diet at least for limited periods. Other than questions of taste, which were unanimously brought up but also dismissed as being the easiest to control, they mentioned the availability of food products ("if all you can find between the lessons is bread with something and a juice [un pan con algo y un jugo], which is carbohydrates and sugar, what can you do?', 'if there's nothing else, you eat a sweet [un dulce] and you are full for another lesson'), the lack of time to go out for a proper meal ('sometimes clients are late, you only have ten minutes before your other lesson starts, you drink un jugo and you go back to work', 'sometimes I only have time to go to the nearest pizzeria, I buy a pizza and un refresco [soda / soft drink], and that is all my food)' Yet as seen earlier - the energy boosting potential of sugar, which is a must on days filled with private lessons and group lessons that do bring revenue but also put a lot of pressure on the body.

Finally, many of my research participants indicate that weight loss and maintaining what is believed to be a beautiful figure are key to holding on to a relationship, as expressed by Yasnara, in her comparison of Cuban men and European men: 'Maybe European men are a bit more responsible, I don't know. Here, you get a little fatter, sometimes because you just do, other times because you are pregnant, you are going to give birth to his child, and he's already off looking for someone else, because you no longer look good enough for him'.

Yasnara's comment highlighting the ultimate importance of sexual attraction is better understood in the broader context of romantic and sexual involvements that have characterized Cuban tourism ever since the country reopened to foreign visitors. As my previous research indicates, dance and images of romantic love or raw, unrestrained sexuality communicated through performances often led to a fluid understanding of affection on both sides. The romantic theme has become central to Western consumption, being inscribed in a 'complex pattern of hedonistic behavior, the majority of which occurs in the imagination of the consumer' (Campbell 1987: 89). This pattern frames touristic behavior and constructs an exotic Other imagined as more passionate, emotional, and sexually tempting (Pruitt, LaFont, 1995). While relationships between Cuban women and foreign tourists are usually perceived as strictly sexual, especially when it comes to AfroCuban women (Fusco, 1998), those between Cuban men and female tourists are thought of as having a romantic or emotional component; this reinforces the sexual fantasies that attract women to the Caribbean, even though the economic aspect is not neglected and often plays a key role (Kempadoo, 2004; Simoni, 2015). 
It was repeatedly pointed out to me, especially during interviews with male dancers, that foreign women who come to Cuba for dance lessons usually expect more from their potential dance partners / dance teachers. Jorge, a twenty-year-old dancer, explained this dynamic as follows: 'In Europe, if you are a little older, let's say in your fifties, and you are single, nobody will look at you. But if you come here and you have some money, you can easily find a boyfriend (novio), it doesn't matter if you are old or ugly or fat. This is how poor countries sell themselves.' Jorge's perception of the instrumental and purely economically motivated relationships between foreign women and Cuban men, as well as Yasnara's comment on the superficial behavior of Cuban men when in relationship with foreign women, point to a certain duality or double standard when it comes to perceptions of the female body. Normativity displayed in relation to Cuban women is almost entirely disregarded when relationships become transactional. While male dancers usually capitalize on skin color (thus reinforcing colonial sexual stereotypes), women have to adhere to stricter standards. And while a curvier body - in line with the Western ideal of the Caribbean body-is considered desirable, it excludes any excessive body fat, implies perfectly flat abdominals, firm buttocks, and well-defined arms. In many cases, good looks are understood as the key to getting more clients and to being in control of the clients with whom one has to dance. Milena, a twenty-two-year-old dancer who in the course of a few months had changed three dance schools looking for better economic opportunities told me the following:

If you don't go out at parties, to look for clients, to dance with them, and get them to take dance lessons with you, you have to settle for the ones you get [from the boss] (los que te tocan). And sometimes they are very rude, they think they own you and they can dance as close as they want, to touch you wherever they want, because they are paying and they are leaving a ten CUC tip to your boss. But to go out and find your clients you have to have the looks, and besides it takes a lot of sacrifice. I already have a son, last week I had to have an abortion because I got pregnant again and I couldn't afford another pregnancy, another child. I couldn't put my body through that again'.

Milena's story highlights the multidimensional understanding of Cuban dancers' concerns - from the pressure to make ends meet as a self-employed worker, to providing for her family, and maintaining her body within accepted beauty standards that ultimately ensure clients and therefore hard currency. This is strengthened by an idealized and simplified imaginary put forward by the tourism industry, which which Cuban dancers are constantly confronted. It is especially true of programs aimed at women who seek to develop their dancing skills and (re)discover their femininity through immersion in Cuban dance, thus 
operating with an idealized model of femininity embodied by Cuban dancers, a model to be treated as a source of inspiration.

The dominance of sugar cultivation and sugar exports has defined the Cuban economy and Cuban life for centuries. Shaped by slavery, colonialism, and plantation culture, Cuba has reoriented its economy towards tourism, and heritage tourism in particular, as a result of the collapse of the Soviet Union and the loss of its most important trade partner. One of the island's most important tourist attractions, Trinidad and the surrounding Valle de los Ingenios, is also the only World Heritage site in the Caribbean dedicated to sugar history. Yet sugar itself turns out to be extremely ambivalent heritage, especially in everyday practice.

The belief in the virtues of sugar in the Caribbean dates back to nineteenthcentury practices, and its 'ritualization' (Mintz, 1986) relates to the added energy and swift sensation of satisfaction. Although recognized as an important source of energy for dancers who work in the private sector (therefore subjected to flexible work regimes and constantly expected to adapt themselves to the needs of dancing tourists) it is also considered an impediment to achieving the ideal figure. While prevailing Western descriptions of Cuban women tend to idealize an assumed freedom from the effects of global neoliberalism, by also highlighting the oversexualization and commodification of the female body in Cuba, local definitions and ideals of beauty challenge these perceptions and reveal complicated and contradictory approaches to body image, ideals of beauty, and, ultimately, food consumption.

Dance forms and their transnational circulation, as a result of their increased international popularity, have revealed not only processes of commodification and standardization of these forms and a rapidly growing market developed around dance, but also powerful ideas of beauty and gendered bodies, which, much like some of the dance forms, were readapted as they came back to Cuba and given new meanings in practice.

\section{ACKNOWLEDGMENTS}

I would like to thank Renata E. Hryciuk for her support with the first drafts of this article and for her insistence that I should write it in the first place as well the two anonymous reviewers for their valuable observations. 
Research conducted for this article was part of the project funded by the National Science Centre, Poland, number 2017/25/N/HS3/00315.

\section{REFERENCES}

Alfonso, I. D. (2012). We are What We Now Eat: Food and Identity in the Cuban Diaspora. Canadian Journal of Latin American and Caribbean Studies/Revue canadienne des études latinoaméricaines et caraïbes, 37(74), pp. 173-206.

Alvarez, J. (2004). Overview of Cuba's food rationing system. Department of Food and Resource Economics, Florida Cooperative Extension Service. Gainesville: University of Florida.

Ana, R., Lubiński, O. (2014). Not Exotic Enough? Implications of the Duality of Cuban Foodways on the Tourist Market. Maska, 24(4), pp. 119-128.

Blanco Borelli, M. (2016). She is Cuba. A Genealogy of the Mulata Body. New York, NY: Oxford University Press.

Brenner, P., Jiménez, M. R., Kirk, J. M., LeoGrande, W. M. (2015). History as Prologue: Cuba before 2006. In P. Brenner et al. (eds.), A Contemporary Cuba Reader. The Revolution under Raúl Castro (pp. 1-31). Lanham, MD: Rowman \& Littlefield.

Brumann, C. (2014). Heritage agnosticism: a third path for the study of cultural heritage. Social Anthropology, 22(2), pp. 173-189.

Campbell, C. (1987). The Romantic Ethic and the Spirit of Modern Consumerism. London, UK: Blackwell.

Carter, A. (2013). Cuba's Food-Rationing Systems and Alternatives. Case study \#4-6 of the program: 'Food Policy for Developing Countries: The Role of Government in the Global Food System'. Ithaka, NY: Cornell University.

Chelcea, L. (2014). Work-discipline and Temporal Structures in a Multinational Bank in Romania. In N. Makovicky (ed.), Neoliberalism, Personhood, and Postsocialism: Enterprising Selves in Changing Economies (pp. 37-52). Farnham, UK: Ashgate.

Curtin, P. (1969). The Atlantic Slave Trade: A Census. Madison: University of Wisconsin Press.

Daigle, M. (2015). From Cuba with Love. Sex and Money in the Twenty-First Century. Oakland: University of California Press.

Davidson, M. J., Krull, C. (2011). Adapting to Cuba's Shifting Food Landscapes: Women's Strategies of Resistance. Cuban Studies, (42), pp. 59-77.

Espino, M. D. (1993). Tourism in Cuba: A Development Strategy for the 1990s? Cuban Studies, (23), pp. 49-69.

Folch, C. (2008). Race in Prerevolution Cuban Cookbooks. Latin American Research Review, 43 (2), pp. 205-223. 
Fusco, C. (1998). Hustling for Dollars. Jineterismo in Cuba. In: K. Kempadoo, J. Doezema (eds.): Global Sex Workers. Rights, Resistance, and Redefinition (pp. 151-166). London: Routledge.

Galván, J. A. (2004). Sugar and Slavery: The Bittersweet Chapter in the 19th Century Cuba, 18171886. Revista de Humanidades: Tecnológico de Monterrey, (16), pp. 211-231.

Garth, H. (2013). Resistance and Household Food Consumption in Santiago de Cuba. In C. Counihan, V. Siniscalchi (eds.), Food Activism: Agency, Democracy and Economy (pp. 47-60). New York NY: Bloomsbury Academic.

Garth, H. (2017). There is no food: Coping with Food Scarcity in Cuba Today. Hot Spots, Cultural Anthropology website. Retrieved from https://culanth.org/fieldsights/1084-there-is-no-foodcoping-with-food-scarcity-in-cuba-today.

Garth, H. (2019). Alimentary Dignity: Defining a Decent Meal in Post-Soviet Cuban Household Cooking. The Journal of Latin American and Caribbean Anthropology, 24(2), pp. 424-442. https://doi.org/10.1111/jlca.12369

Goucher, C. (2015). Congotay! Congotay! a Global History of Caribbean Food. London, UK: Routledge.

Honychurch, L. (2005). Caribbean heritage: its uses and economic potential. In Caribbean Wooden Treasures. Proceedings of the Thematic Expert Meeting on Wooden Urban Heritage in the Caribbean Region, 4-7 February 2003, Georgetown, Guyana (pp. 27-32). Paris, France: UNESCO World Heritage Centre.

Hryciuk, R. (2009). Kobiecość, męskość, seksualność. Płeć kulturowa (gender) w badaniach Ameryki Łacińskiej. In M. Gawrycki (ed.), Cywilizacja Latynoamerykańska (pp. 270-285). Warsaw, Poland: PWN.

Inniss, T.A., Jolliffe, L. (2012) The Industrial Heritage of Sugar at World Heritage Sites in the Caribbean. In L. Jolliffe (ed.), Sugar Heritage and Tourism in Transition (pp. 89-109). Bristol, UK: Channel View.

Kempadoo, K. (2004). Sexing the Caribbean: Gender, Race, and Sexual Labor. New York, NY: Routledge.

Kirk, E.J. (2011). Setting the Agenda for Cuban Sexuality: The Role of Cuba's Cenesex. Canadian Journal of Latin American and Caribbean Studies, 36(72), pp. 143-163. https://doi.org/10.1080/08263663.2011.10817018

Krohn, F. B., O’Donnell, S. T. (1999). U.S. Tourism Potential in a New Cuba. Journal of Travel \& Tourism Marketing, 8(1), pp. 85-99.

Lasansky, D. M. (2004). Tourist Geographies: Remapping Old Havana. In D. M. Lasansky, B. McLarens (eds.), Architecture and Tourism (pp. 165-186). Oxford, UK: Berg.

Mintz, S. (1986). Sweetness and Power. The Place of Sugar in Modern History. New York, NY: Penguin Books.

Ortiz, F. (1995). Cuban Counterpoint. Tobacco and Sugar. Durham, NC: Duke University Press. 
Pérez, L. A. (1983). Cuba between Empires, 1878-1902. Pittsburgh, PA: University of Pittsburgh Press.

Philllips, E. (2006). 'Cuentapropismo' in a Socialist State. In M. Font (ed.), Cuba: In Transition? Pathways to Renewal, Long-Term Development and Global Reintegration (pp. 107-124). New York, NY: Bildner Center for Western Hemisphere Studies.

Pollitt, B. H. (2004). The Rise and Fall of the Cuban Sugar Economy. Journal of Latin American Studies, 36(2), pp. 319-348.

Pollitt, B. H. (2010). From Sugar to Services: An Overview of the Cuban Economy. Monthly Review Online. Retrieved from https://mronline.org/2010/10/06/from-sugar-to-services-anoverview-of-the-cuban-economy/.

Pruitt, D., LaFont, S. (1995). For Love and Money. Romance Tourism in Jamaica. Annals of Tourism Research, 22(2), pp. 422-440.

Sanchez, P. M., Adams, K. M. (2008). The Janus-faced character of tourism in Cuba. Annals of Tourism Research, 35(1), pp. 27-46.

Scarpaci, J. L. (2005). Environmental Planning and Heritage Tourism in Cuba During the Special Period: Challenges and Opportunities. In J. Pugh, J. Henshall Momsen (eds.), Environmental Planning in the Caribbean (pp. 73-92). Burlington, UK: Ashgate.

Simoni, V. (2015). Breadwinners, sex machines and romantic lovers: entangling masculinities, moralities, and pragmatic concerns in touristic Cuba. Etnógrafica, 19(2), pp. 389-411.

Smith, L. M., Padula, A. (1996). Sex and revolution: Women in socialist Cuba. Oxford, UK: Oxford University Press.

Tomé, L. (2017). Swans in Sugarcane Fields: Proletarian Ballet Dancers and the Cuban Revolution's Industrious New Man. Dance Research Journal, 49(2), pp. 4-25. https://doi.org/10.1017/S0149767717000171

Wilson, M. (2009). Food as a good versus food as a commodity: Contradictions between state and market in Tuta, Cuba. Journal of the Anthropological Society of Oxford, 1(1), pp. 25-51.

Zanetti, O., Garcia, A. (1998). Sugar \& Railroads. A Cuban History, 1837-1959. Chapel Hill: University of North Carolina Press. 
